\title{
The regional consumer market as a factor of structural shifts in energy resources consumer economy of the region
}

\author{
$O K$ Lukhovskaya*, $T S$ Kochetkova and $Y$ E Zhukova
}

Plekhanov Russian University of Economics, Ivanovo branch, 153025, Ivanovo, Dzerzhinsky St., 53, Russia

\begin{abstract}
The role of the consumer market in effective sales policy formation in power engineering of regions is not debatable. According to project estimates it is necessary to accept that the regional consumer market is strategically important factor of the energy market structural changes in regions of Russia. Its balanced development provides the acceleration of progressive structural changes in their economy. The scientific results given in the article and obtained by the authors are directed to the consumer market justification as one of the leading strategic factors of power engineering development in regional economy structure, in particular in Ivanovo region, and analysis of its growth influence at energy resources consumption efficiency. It is shown that the main consequence of structural transformations in economy was the sharp decline in industrial production (in particular, in textile manufacture of the Ivanovo region) which was followed by decrease in energy consumption and its growth in service sector. Currently the consumer market acts as the dominating factor in electricity consumption and formation of regional electricity balance. These researches are aimed at justification of this conclusion at the moment.
\end{abstract}

\section{Introduction}

The regional energy market should be characterized as the major and one of the main components of modern economy. It provides the formation of that part of GRP materialized in the form of the produced goods and services as delivery objects of thermal and electric energy which is bought for ensuring activity of economic entities (the organizations and the enterprises) and the population of the region for personal consumption. The important social and economic role in sales policy of the power engineering sphere plays the consumer market uniting economic entities of service sector, i.e. consumers of energy resources [1].

We mean by 'the consumer market economic entities' any legal entities and individual entrepreneurs in the sphere of wholesaling and retailing of consumer goods, public catering and in service sector [2].

The consumer market acts as the institute which contributes to the regional power engineering development [3]. In scientific literature we meet the definition of the consumer market in its narrow meaning - as the market of buyers or consumers ("individuals and households") [4].The process of obtaining goods and services should be considered more widely as the bilateral act in which presence of other side subjects (sellers) is obligatory[5]. This essential distinctive consumer market characteristic as economic category shows the specificity of the energy market in the most appropriate way.

It will be useful to study the identification of duality in energy market characteristic and features of power engineering component of the consumer market which are the following.

On one hand, all consumer market economic entities (according to our characteristics) act as consumers at the energy market. Energy resources are important components of their economic potential. In total the consumed energy resources in the consumer market allow to form the gross value added of GRP in service sector.

On the other hand, producers of products act as consumers at energy market which in total energy resources consumption allow to form the gross value added of GRP in the goods production sphere. Such types of economic activity as the processing productions, agriculture, hunting and forestry, fishery, fish farming; mining; energy, gas and water production and distribution, construction belong to the material sphere.

Energy resources as a technological component of goods production come to the market in natural kind. They are formed into the system of 'commodity-money' and organizational and economic relations as economic resources. In this regard the energy market should be considered as a form of the organization of the circulation sphere in material production. It provides interrelations of energy resources regional production, their distribution, exchange and consumption for manufacturing goods. In that case the energy market is the main technological component of material production economy and consumer market. It is necessary to recognize that the consumer market is the leading strategic factor of power engineering development in economics structure of number of the

\footnotetext{
* Corresponding author: ollga37@yandex.ru
} 
Table 1. Electric-power consumption of extracting and processing productions workers and production and power distribution of gas and water in 2012-2018 (kW/h) [10].

\begin{tabular}{|l|c|c|c|c|c|}
\hline \multicolumn{1}{|c|}{ Indicators } & $\mathbf{2 0 1 8}$ & $\mathbf{2 0 1 7}$ & $\mathbf{2 0 1 6}$ & $\mathbf{2 0 1 4}$ & $\mathbf{2 0 1 2}$ \\
\hline average in the CFD & 47088 & 45492 & 43079 & 43004 & 40292 \\
\hline Belgorod region & 96782 & 94147 & 92838 & 91800 & 93626 \\
\hline Kursk region & 84960 & 82976 & 80847 & 83170 & 76191 \\
\hline Lipetsk region & 105634 & 102826 & 102812 & 95858 & 89228 \\
\hline Smolensk region & 50272 & 50987 & 47550 & 45608 & 42059 \\
\hline Tula region & 44516 & 44139 & 46842 & 45695 & 44536 \\
\hline
\end{tabular}

Russian Federation regions, to justify that and to direct researches of processes of its growth influence at energy resources consumption efficiency.

\section{Methods}

Material production was always the essential component of the power engineering industry. According to statistical data, nowadays energy consumption remains the strategically important resource of the Russian Federation material production economy. The vivid confirmations of this conclusion are the calculations with application of gross regional product power consumption techniques [6].

Authors established the leading role of the consumer market in GRP formation, but its role in region power recession impact on material production on a region energy balance is not researched and the forecast of energy resources consumption in the market is not created [7].

The analysis of these processes on the example of the Ivanovo region allows expanding a scope of the methodical programmes presented by authors in the field of assessment and diagnostics of regional consumer market development [8]. We will take the key points of Concept of the regional economy and the consumer market development made by group of authors under the leadership of professor O.K. Lukhovskaya as a methodological basis. Application of diagnostic techniques and the regional consumer market forecasting made byD.V. Turtin will allow to estimate in 2 stages (diagnostics (1 stage) and forecasting (the 2nd stage)) its growth impact on efficiency of regional energy resources consumption [9].

\section{Results}

As a rule, the increase of energy resources consumption in material production and contribution growth of this sector to the regional economy is provided in industrially developed regions of the Russian Federation. We point our attention to five of 17 subjects of the CFD Belgorod, Kursk, Lipetsk, Smolensk and Tula regions. The analysis of country electricity balance allows to state about maintaining positive dynamics in energy resources consumption in the main sectors of goods production of these Russian Federation territorial subjects. Despite the positive dynamics of the consumer market growth, the main contribution to economy of these regions provides the branches of material production.

The volume of the electric power consumed by the industrial organizations per one worker in these regions is high and it exceeds average indicators of electricpower consumption per unit of labour of extracting and processing production workers and production and power distribution of gas and water on average in the CFD (table 1).

The electric power in other CFD subjects is more consumed in the non-productive purposes that allows to regulate the dominating role in regional economy development of the consumer market uniting economic entities which are the consumers of service sector energy resources. As an example, we consider these processes on the base of the Ivanovo region, textile cluster of Russia [11].

Our researches proved that for a long period of time (since 2006) material production has not been the leading sphere in formation of GRP in Ivanovo region [8].

Decline of material production and turnover of production infrastructure of Ivanovo region from 54.5\% (2003) to $25.9 \%$ (2017) directly influenced to decrease in a share of the manufacturing industries in structure of GRP (figure 1). It is taken into consideration that the structural shifts were caused by the forced development of the consumer market, growth of its turnovers and decrease in a share of material production.

To determine the trend of electricity consumption to the Russian Federation we carried out its analysis (figure. 2). We will present the studying of these indicators in a regional section on the example of Ivanovo region.

The power engineering, included in the sphere of material production, plays one of the leading roles in the system of planning of social and economic development of the Russian Federation[12].The increase of GRP on the account of growth in utilization of capacity and the accelerated implementation of new technologies is a strategic goal of the development of Russia.

The analysis of electricity consumption in the Russian Federation confirms the growth trend with the exception of 2009, 2013. Significant decrease in the amount of consumption in these years was influenced by the crisis of economy connected with the consequences of the global financial crisis.

Strategic plans of power engineering development also provided the balanced growth of region economy and assessment of complex impact on regional economic 


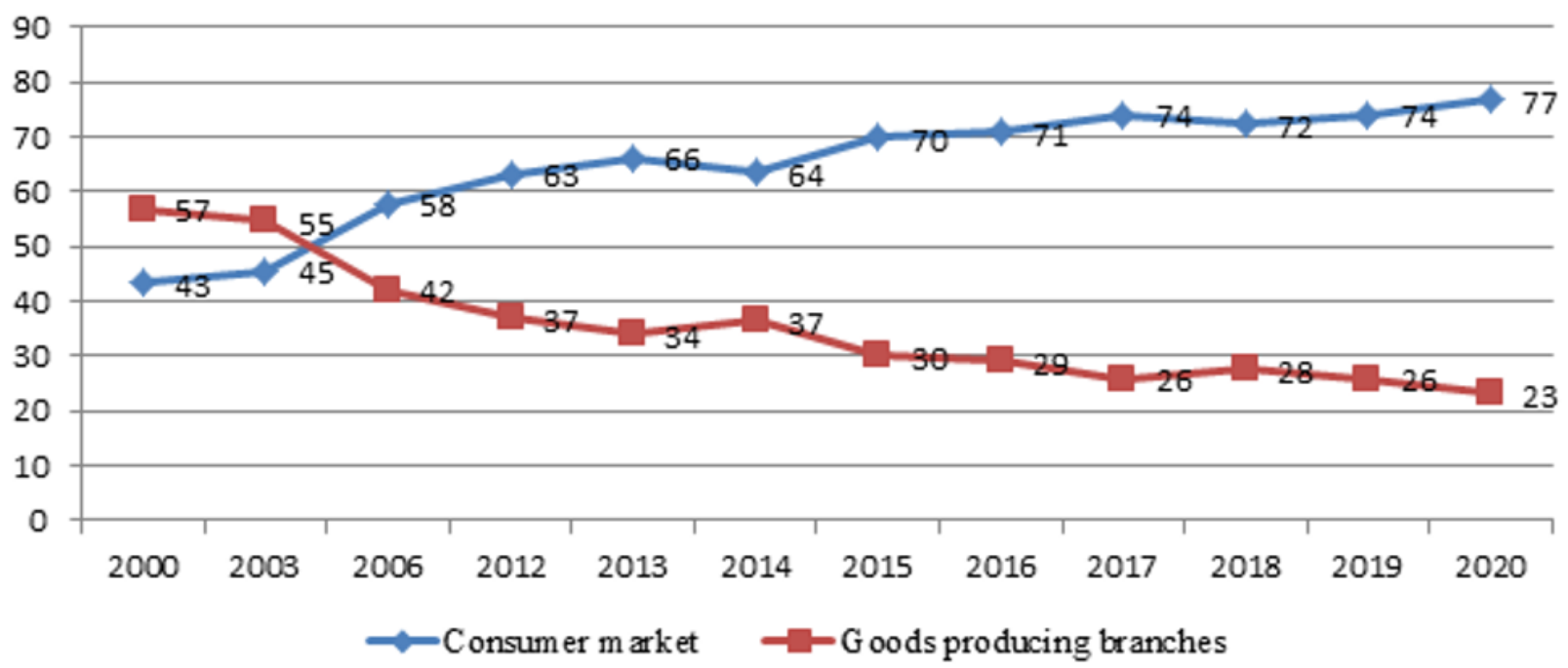

Fig. 1. Dynamics and forecast of goods production turnover change and consumer market in structure of Ivanovo region economy, $\%$.

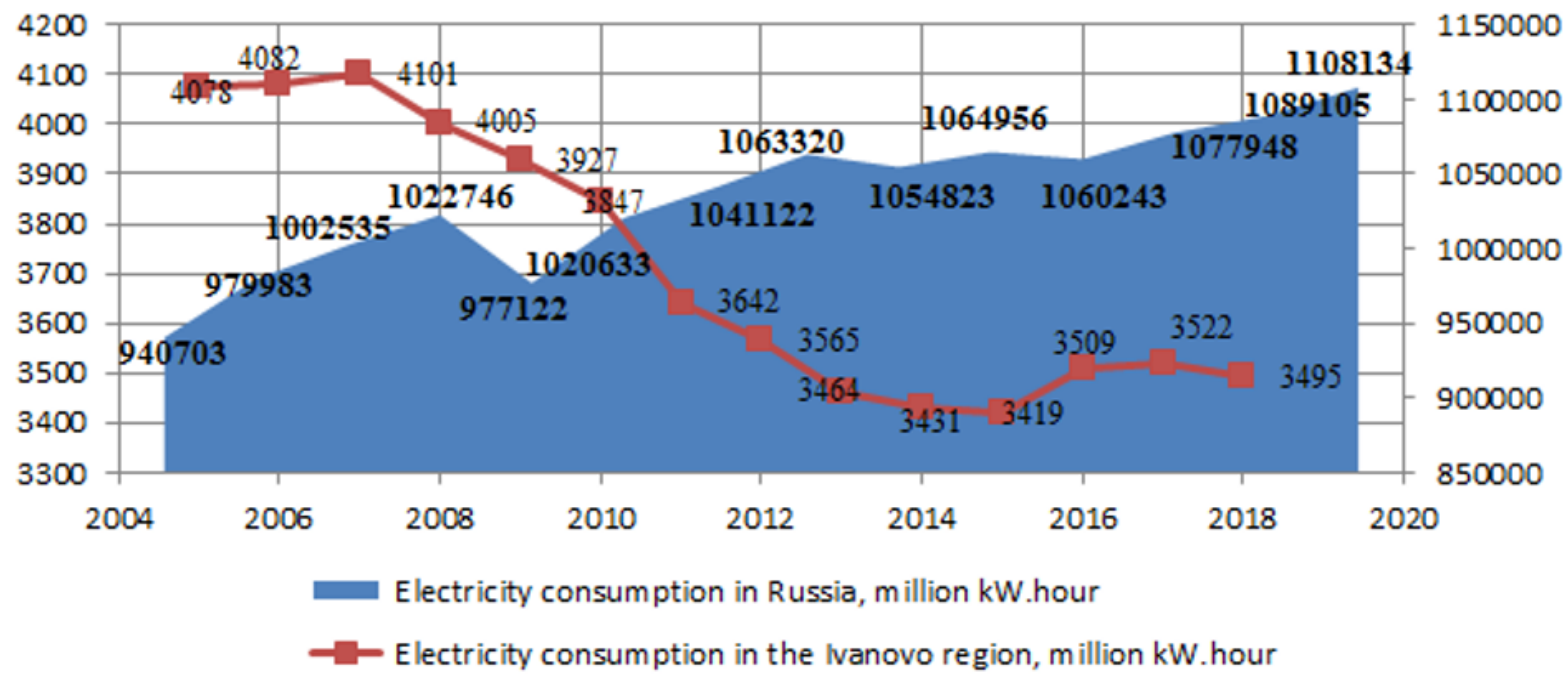

Fig. 2. Dynamics of electricity consumption in the Russian Federation and Ivanovo region -2018, one million kW/h.

dynamics of all factors and reserves, including power, in Ivanovo region till 2020 (developed in 2010 [13]).

In fact, electricity consumption in Ivanovo region, on the contrary, has a negative trend. For the considered period of time (2005-2018) recession was $14.3 \%$, it was mainly caused by the reduction of industrial production

Table 2. Dynamics of economic indicators, the analysis of planned values performance and a share type of economic activity "Production and distribution of power, gas and water" in GRP of the Ivanovo region, 2012-2018, mln rub.at basic prices of the corresponding years[14].

\begin{tabular}{|l|l|l|l|l|l|l|l|}
\hline \multirow{2}{*}{ Indicators } & \multicolumn{2}{l}{$\begin{array}{l}\text { Gross regional product } \\
\text { (GRP), mln rub. }\end{array}$} & \multicolumn{2}{l}{$\begin{array}{l}\text { Production and distribution of power, } \\
\text { gas and water (PDPGW), mln rub }\end{array}$} & \multicolumn{2}{l|}{$\begin{array}{l}\text { Deviations } \\
\%\end{array}$} & $\begin{array}{l}\text { PDPGW } \\
\text { share in GRP } \\
\text { in }\end{array}$ \\
\cline { 2 - 7 } & Plan & Fact & Plan & Fact & GRP & PDPGW \\
\hline 2012 & 143244.3 & 136122.0 & 25237.6 & 23531.1 & 95.0 & 93.2 & 17.2 \\
\hline 2013 & 158262.1 & 150286.2 & 28064.9 & 25609.8 & 94.9 & 91.3 & 17.04 \\
\hline 2014 & 175775.4 & 151047.0 & 29703.9 & 26531.3 & 85.9 & 89.3 & 17.5 \\
\hline 2015 & 194688.8 & 158819.1 & 31801.0 & 26671.3 & 81.5 & 83.9 & 16.8 \\
\hline 2016 & 217066.3 & 179633.4 & 33457.8 & 28257.6 & 82.7 & 84.5 & 15.7 \\
\hline 2017 & 216934.5 & 191802.1 & 35236.1 & 28610.8 & 88.4 & 81.2 & 14.9 \\
\hline 2018 & 209127.6 & 197338.7 & 32097.4 & 29298.1 & 94.4 & 91.3 & 14.0 \\
\hline
\end{tabular}


share in structure of regional economy (first of all, the textile industry) and by the increase of service sector share.

\section{Discussion}

Planned economic indicators of economic activity "Production and distribution of power, gas and water" are not fulfilled and dynamics of decrease in its share in GRP is observed (table 2).

Structural shifts in the regional GRP first of all were caused by the forced development of its separate components as trade, education, health care which allowed to establish the leading role of the consumer market in electricity consumption and formation of electricity balance in regions.

We will analyze the distribution of electricity consumption in the Ivanovo region according to types of economic activity (table 3 ).

Since 2012 such economic activity as "Wholesale and retail trade" has been allocated as a separate article in the electricity balance. The authors conducted a number of studies in the diagnostics of this area[15]. The dominating role of trade sphere in the consumer market is proved. The analysis of the share of electricity consumption in the trade of the Ivanovo region is another confirmation of its importance in the development of the region's economy, the consumer market of service and the energy market. The share of trade in energy consumption is twice higher than the

Table 3. Distribution of electricity consumption in the Ivanovo region according to economic activities, million $\mathrm{kW} / \mathrm{h}^{\mathrm{a}}$.

\begin{tabular}{|c|c|c|c|c|c|c|c|c|}
\hline Economic activity & 2005 & 2010 & 2014 & 2015 & 2016 & 2017 & 2018 & $\begin{array}{c}\text { The growth } \\
\text { rate } \\
\text { 2018/2005., \% }\end{array}$ \\
\hline $\begin{array}{l}\text { Mining, processing industries, } \\
\text { provision of electricity, gas; } \\
\text { water supply }\end{array}$ & 1986.3 & 1614.7 & 1119.9 & 1121.0 & 1138.9 & 1147.8 & 1130.0 & 56.89 \\
\hline $\begin{array}{l}\text { Agriculture, forestry, hunting, } \\
\text { fishing and fish farming }\end{array}$ & 134.5 & 94.4 & 81.5 & 81.6 & 82.2 & 82.3 & 80.7 & 60.00 \\
\hline Construction & 35 & 33.1 & 33.1 & 33.0 & 32.5 & 33.4 & 33.4 & 95.43 \\
\hline Total: material production & 2155.8 & 1742.2 & 1234.5 & 1121.0 & 1253.6 & 1263.5 & 1244.1 & 57.7 \\
\hline Wholesale and retail trade & - & - & 94.6 & 93.2 & 93.0 & 96.1 & 97.1 & - \\
\hline Transportation and storage & \multirow[t]{2}{*}{199.9} & \multirow[t]{2}{*}{232.1} & \multirow[t]{2}{*}{231.3} & \multirow[t]{2}{*}{226.7} & \multirow[t]{2}{*}{232.2} & 221.8 & 213.6 & \multirow[t]{2}{*}{120.16} \\
\hline $\begin{array}{ll}\text { Information } & \text { and } \\
\text { communication activities }\end{array}$ & & & & & & 26.5 & 26.6 & \\
\hline Other economic activities & 514.6 & 753.1 & 696.6 & 695.7 & 732.7 & 686.3 & 686.3 & 133.37 \\
\hline Urban and rural population & 711.4 & 751.5 & 760.9 & 762.0 & 791.7 & 821.8 & 824.3 & 115.87 \\
\hline Total:consumer service market & 1425.9 & 1736.7 & 1783.4 & 1777.6 & 1849.6 & 1852.5 & 1847.9 & 129.6 \\
\hline
\end{tabular}

Table 4. Analysis of the share of the consumer market in GRP and the dynamics of the share of energy consumption in the consumer market of the Ivanovo region.

\begin{tabular}{|c|c|c|c|c|}
\hline \multirow[t]{2}{*}{ Year } & \multicolumn{2}{|c|}{$\begin{array}{l}\text { The structure of GRP by economic activity, mln } \\
\text { rub }^{\text {a }}\end{array}$} & \multicolumn{2}{|c|}{ Structure of electricity consumption, million $\mathrm{kW} / \mathrm{h}^{\mathrm{b}}$. } \\
\hline & Material production & Consumer market & Material production & Consumer market \\
\hline 2006 & 23192.89 & 31897.11 & 1941.2 & 1539.8 \\
\hline 2010 & 50752.8 & 76447.2 & 1742.2 & 1736.7 \\
\hline 2012 & 50228.28 & 85891.72 & 1515.5 & 1696.7 \\
\hline 2013 & 53639.97 & 104590.03 & 1425.4 & 1691.7 \\
\hline 2014 & 55436.20 & 96443.80 & 1234.5 & 1783.4 \\
\hline 2015 & 54336.52 & 126183.48 & 12356 & 1777.6 \\
\hline 2016 & 52272.33 & 127357.67 & 1253.6 & 1849.6 \\
\hline 2017 & 50059.80 & 141740.20 & 1263.5 & 1852.7 \\
\hline \multicolumn{5}{|c|}{ The predicted values of the indicators } \\
\hline 2019 & 57510.75 & 151619.25 & 1244.1 & 1847.9 \\
\hline 2020 & 57892.41 & 163917.59 & 1215.4 & 1859.3 \\
\hline \multicolumn{5}{|c|}{$\begin{array}{l}{ }^{a} \text { Data for the Ivanovo region are systematized from materials "Forecasts of social and economic development of the Ivanovo } \\
\text { region". Resolutions of the Government of the Ivanovo region: from } 28.06 .2013 \text { No. } 252-p \text {; from 08.08.2014 No. 331-p; from } \\
\text { 10.11.2016 No. 374-p; from 27.10.2017 No. 381-p; from 31.10.2018 No. 305-p//http://www.ivanovoobl.ru/region/sotsial-no- } \\
\text { ekonomicheskoe-razvitie-ivanovskoj-oblasti } \\
\text { bata for the Ivanovo region are systematized from the materials of Electricity balance of the Russian Federation by years: } \\
\text { htttp://www.gks.ru/free_doc/new site/business/prom/el_balans } 05 ; 10 ; 14 ; 15 ; 16 ; 17 ; 18 . \mathrm{htm}\end{array}$} \\
\hline
\end{tabular}




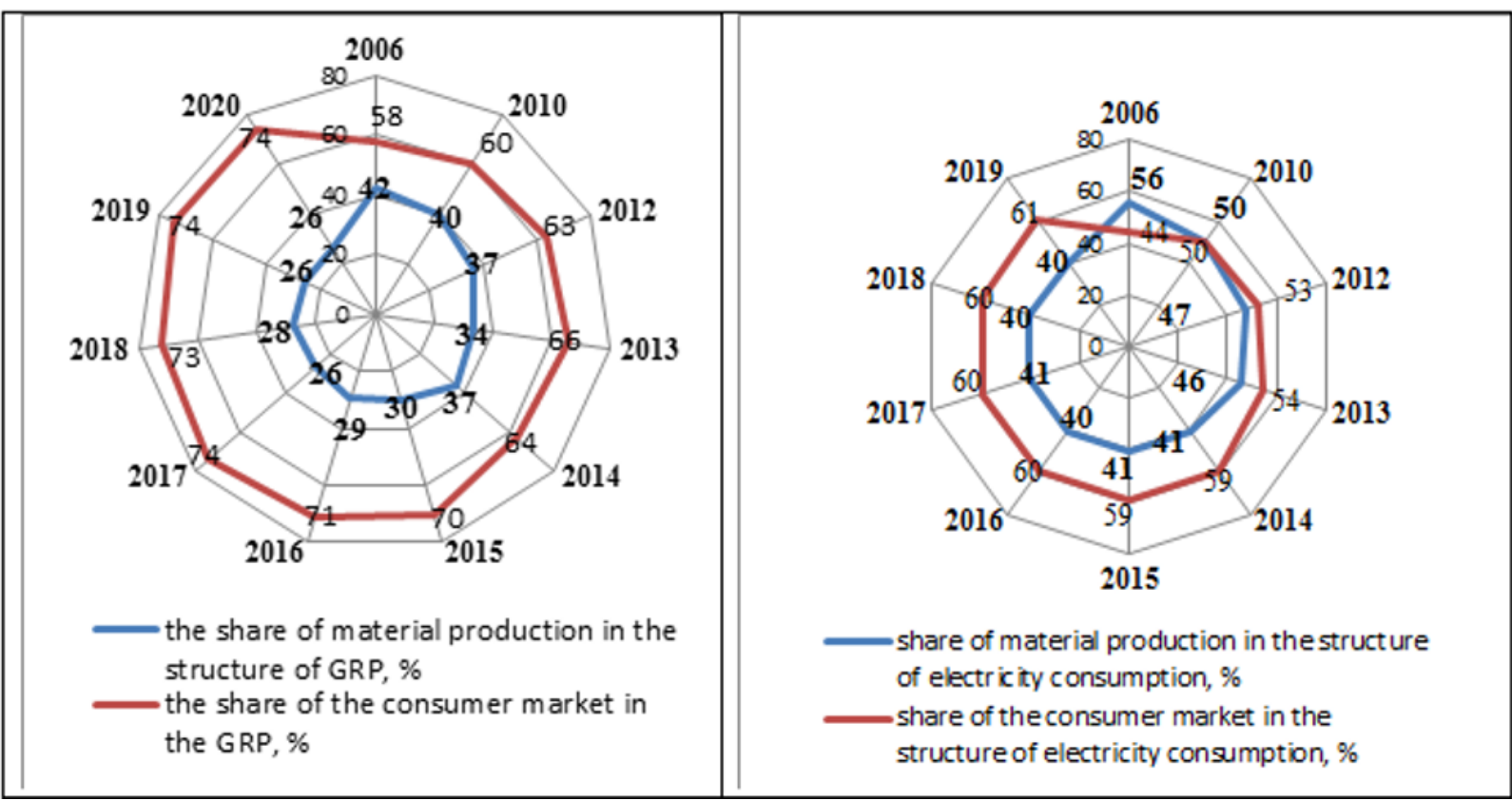

Fig. 3. Material production and consumer market in the structure of GRP and electrical balance in the Ivanovo region, $2006-$ $2020, \%$.

share of consumption in construction and has been ahead of consumption in agriculture, forestry, hunting, fishing and fish farming since 2014.

For justification of the consumer market as one of the leading strategic factors of power engineering development in regions economy structure it will be analyzed growth dependence of its share in GRP and dynamics efficiency of energy resources consumption in the consumer market of Ivanovo region.

The methods of diagnostics and forecasting of energy consumption depending on the development of the consumer market of the region are based on the methods of D. V. Turtin [9].

The indicator of the volume of electricity consumed in the material production and consumer market of the Ivanovo region was chosen as an effective sign. The data of the Federal statistics service were used [10].

The forecast of indicators in the application of the method of D. V.Turtin is presented in table 4,figure 3 .

\section{Conclusions}

The growth of the consumer market in the structure of GRP of the Ivanovo region is ahead of its growth in energy consumption. Thus, in 2006, the consumer market occupied a large share in the structure of GRP in comparison with material production and made a total of $57.9 \%$. The annual growth share ranged from $1 \%$ (2016) to $6.4 \%$ (2015).

The increase in electricity consumption was mainly provided in the following spheres:

- transport and communications (growth rate for $2018 / 2005-120.16 \%)$

- urban and rural population (growth rate for $2018 / 2005-115.87 \%$ ).
- other economic activities (growth rate for $2018 / 2005-133.37 \%$ ), in which a special role is given to the sphere of wholesale and retail trade.

A large share of material production in the structure of electricity consumption remained the same until 2010 . Decreasing further annually by an average of $2.7 \%$, the share of material production in the structure of electricity consumption in 2017 amounted to $30.6 \%$, almost a third of the electricity balance of Ivanovo region. Thus, 69.4 $\%$ of electricity is consumed by economic entities of the consumer market.

It should be noted that in the studied period of time there is a significant reduction in electricity consumption of the following activities:

- mining, processing industries; provision of electricity, gas and steam; air conditioning; water supply; water disposal; waste collecting and recycling; activities for the elimination of pollution (growth rate for 2018/2005 - 56.9\%);

- agriculture, forestry, hunting, fishing and fish farming (growth rate for 2018/2005-60.00\%).

Our study was aimed to analyze the impact of the growth of the consumer market in the region on the efficiency of energy consumption. The study showed that the consumer market is currently the dominant factor in the consumption of electricity and is one of the leading strategic factors in the power engineering development in the structure of the economy of the regions.

\section{References}

1. O.K. Lukhovskaya, Trends in the development of the consumer market in the modern economy of the region, Modern trade: theory, practice, innovation. Proceedings of the meeting, VIII n-pract. 
conference with international participation dedicated to the 15th anniversary of the Perm trade and economic educational complex, 29-32 (2018)

2. T. Kochetkova, E.A. Balashova, Development of directions of strategic development and management of region's consumer market, Economics and Management of Management Systems, 26(4-4), 426-433 (2017)

3. M.A. Belyaeva, Modeling of technical and economic systems: textbook, 4, 262 (2018)

4. P. Kotler, Principles of marketing, 356 (2003)

5. O.K. Lukhovskaya, I.V. Malov, I.N. Degtyareva, Methodological approaches to the assessment of the consumer market in modern science. In the collection, the Economy of the regions of Russia: the current state and prospects of the Collection of articles on the materials of the all-Russian npractice. conferences of teachers, graduate students, undergraduates of PRUE. G. V. Plekhanov, 161168 (2019)

6. I.A. Bashmakov, Dynamics of energy intensity of the gross regional product of Moscow [Electronic resource], Executive Director of the Center for energy efficiency (CENEF) https:/www.abok.ru/for_spec/articles.php?nid=489 0 (date of the address: $2 \overline{5} .07 .2019$ ).

7. T.S. Kochetkova, O.Yu. Gur'eva, N.I. Fomin, Diagnosis and strategic decisions for the development of regional trade networks, Bulletin of the Altai Academy of Economics and law, 7, 74-84 (2019)

8. A.I. Gretchenko, N.T. Aref'eva, O.K. Lukhovskaya, D.V. Turtin, T.S. Kochetkova, The concept of economic development and consumer market in the region: science, Monograph, 232 (2017)

9. D.V. Turtin, T.S. Kochetkova, About development of methodical approaches of strategic development of the consumer market of the region, Applied mathematics and Informatics: modern researches in the field of natural and technical Sciences:materials of the V International n-p conference(schoolseminar) of young scientists, 225-229 (2019)

10. Technological development of sectors of the economy[Electronic resource] // http://www.gks.ru/wps/wcm/connect/rosstat_main/r osstat/ru/statistics/economydevelopment (date of the address: 20.07.2019).

11. O.K. Lukhovskaya, L.I. Sharova, M.A. Ananyev, N.A. Gruzintseva, Conceptual foundations of development of textile clusters in the conditions of preservation and reproduction of cultural potential of monoprofile regions, Technology of Textile Industry, 1(367), 5-9 (2017)

12. V.I. Perov, O.K. Lukhovskaya, R.V. Savkina, Comprehensive target programsin the solution of problems of innovative development of economy, Modern HighTechnologies. Regional Supplement, 3(55), 169 (2018)

13. Law of the Ivanovo region "About Strategy of social and economic development of the Ivanovo region till 2020" of 11.03.2010 N 22-OZ in the edition of Laws of the Ivanovo region of 24.03.2011 N 22-
OZ, of 06.06.2011 N 53-OZ, of 07.11.2012 N 87$\mathrm{OZ} \quad$ [Electronic resource] // https://www.google.ru/url (date of the address: 20.07.2019).

14. Forecasts of socio-economic development of the Ivanovo region. Resolutions of the Government of the Ivanovo region: from 28.06.2013 No. 252-p; from 08.08.2014 No. 331-p; from 10.11.2016 No. 374-p; from 27.10.2017 No. 381-p; from 31.10.2018 No. 305-p[Electronic resource] // http://www.ivanovoobl.ru/region/sotsial-noekonomicheskoe-razvitie-ivanovskoj-oblasti (date of the address: 22.07.2019).

15. N.T. Arefieva, O.K. Lukhovskaya, Forecasting and development of sociocultural processes as factor of sustainable region development (2010) 